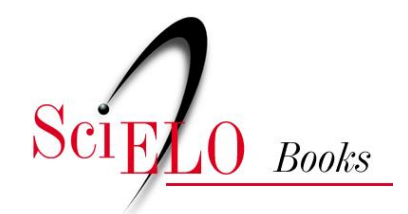

\title{
Formação continuada e as novas tecnologias da informação e comunicação
}

\author{
Eliane de Moura Silva
}

\section{SciELO Books / SciELO Livros / SciELO Libros}

SILVA, EM. Formação continuada e as novas tecnologias da informação e comunicação. In: SOUSA, RP., et al., orgs. Teorias e práticas em tecnologias educacionais [online]. Campina Grande:

EDUEPB, 2016, pp. 7-15. ISBN 978-85-7879-326-5. Available from SciELO Books

$<$ http://books.scielo.org $>$.

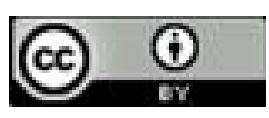

All the contents of this work, except where otherwise noted, is licensed under a Creative Commons Attribution $\underline{4.0 \text { International license. }}$

Todo o conteúdo deste trabalho, exceto quando houver ressalva, é publicado sob a licença Creative Commons Atribição 4.0.

Todo el contenido de esta obra, excepto donde se indique lo contrario, está bajo licencia de la licencia $\underline{\text { Creative }}$ Commons Reconocimento 4.0. 


\section{FORMAÇÃO CONTINUADA E AS NOVAS TECNOLOGIAS DA INFORMAÇÃO E COMUNICAÇÃO}

Precisamos olhar o mundo de hoje com os olhos do mundo de amanhã, não com os do mundo de ontem. Ora, os olhos de amanhã, são os olhos planetários. As fronteiras são as ruínas, ainda de pé, de um mundo em revolução.

(Pierre Lévy)

A Lei de Diretrizes e Bases da Educação Nacional No 9.394/96 regulamentou a Modalidade de Educação a Distância no Brasil. Nos seus artigos 80 e 87, parágrafo $3^{\circ}$, item III legislando sobre a importância da Educação a Distância em programas de Capacitação para Professores em Exercício, assegurando por meio da lei "que o poder público incentivará o desenvolvimento e a veiculação de educação continuada"(LDB, 1999).

A partir de então, teve início, no país, uma mobilização do poder público federal envolvendo as universidades e os poderes estadual e municipal em torno da implementação e expansão da oferta de cursos de formação inicial e continuada direcionada a professores na modalidade a distância. Esse movimento pôs no centro do debate a necessidade de uma nova forma de enxergar a educação brasileira, com reflexos imediatos na formação do professor e no sistema edu- 
cacional em todas as modalidades, exigindo uma reflexão crítica do fazer pedagógico das instituições de ensino superior.

Essa política de formação interferiu imediatamente no pensar de um novo perfil do professor formador e do professor em formação, exigindo desses profissionais uma (re) significação de suas práticas em consonância com os novos paradigmas educacionais que requer de todos os envolvidos estudos e pesquisas no que se refere à construção do conhecimento docente. Portanto, é imperioso que a formação de professores como estratégia política privilegiada para a expansão do curso superior no que se refere à oferta e à mudança de mentalidade acadêmica aconteça não só num momento inicial da carreira, como se pensava anteriormente, mas acima de tudo, durante a trajetória profissional e pessoal do professor. A ideia posta é a de que a formação de professores tanto na formação inicial quanto na formação continuada os prepare com habilidades, competências e capacidades diferenciadas como fator determinante e indissociável da atual revolução tecnológica denominada por Castells (1999) de sociedade da Informação e do Conhecimento.

O desafio reside na constatação de que a Universidade, entendida aqui como Instituição responsável pela formação de profissionais terá que dar respostas às contradições que esta apresenta e as expectativas que se esperam dela. Se por um lado, existem grupos de estudos e pesquisa preocupados sobre como formar professores para a sociedade em curso, por outro, existem professores que resistem a continuar com o mesmo fazer pedagógico que vivenciaram da geração do papel, do lápis e do giz acreditando que a escola não precisa mudar os seus métodos, nem as suas metodologias. Ora, se a geração de hoje é bem diferente da geração do passado em suas formas de agir, de vestir, 
de falar, e de seus estilos de vida, obviamente essa geração não tem o mesmo perfil e comportamentos culturais das gerações passadas.

Para este fenômeno, Piscitelli (2009) corrobora ao definir como os "nativos"a geração de hoje nascida em meio a informação tecnológica, ao computador, aos vídeos games, celulares e internet e os “imigrantes"digitais, para ele, são os que não nasceram nessa era, mas são fascinados por esse universo das inovações e as adotam em seus estilos de vida. Mas afinal imigrantes não são nativos e vive-versa, o que faz a diferença dessa geração com as gerações passadas?

Sobre esta constatação afirma ainda Piscitelli:

Nos encontramos ante uma paradoxal situação: os professores, que são preponderantemente imigrantes digitais, e que não falam uma língua, em vias de extinção, da era pré-digital, estão tentando ensinar a uma população que fala uma linguagem totalmente diferente e que é incompreensível para esses professores imigrantes. Embora o problema quase não seja lido desse modo, grande parte da resistência infanto-juvenil ao ensino hoje hegemônico nas universidades é produto da rejeição dos nativos àqueles que pretendem lhes ensinar a própria linguagem, sendo que eles, os nativos, já falam essa língua arcaica, pois a aprenderam como segunda língua. Um absurdo fadado ao fracasso de antemão. Fica mais claro então o porquê da universidade no lugar arrasado dessa equação? (PISCITELLI, 2009, p.47).

Sem negar essas adversidades, que cobrem essa área de conhecimento os estudos e pesquisas têm demonstrado o quanto tem avançado no país propostas e projetos exitosos de formação de professores utilizando a Educação a Distância como um novo paradigma, para superar o modelo tradicional positivista da educação. De fato, essa modalidade tem tido um papel importante na perspectiva 
de mudança do processo educativo porque possibilita uma inequívoca interação entre formadores e os sujeitos em formação fazendo com que o processo de ensino-aprendizagem se dê numa relação de parceria e de construção coletiva.

Neste contexto, temos o prazer de entregar aos nossos leitores um segundo livro da leva desses Novos Tempos de pensar a Educação brasileira como contributo do papel que a Educação a Distância tem assumido na busca da democratização do ensino superior e na possibilidade de minimizar os desafios da formação de professores da educação básica do Estado da Paraíba.

Desta feita, trata-se de uma coletânea resultante da produção acadêmica dos alunos (professores da educação básica) e professores da UEPB que orientaram e mediaram as ações pedagógicas desenvolvidas pela $3^{\mathrm{a}}$ turma do Curso de Especialização em Novas Tecnologias na Educação, coordenado pelo professor Dr. Robson Pequeno de Souza.

Este curso, o quarto do gênero oferecido pela UEPB, vem firmando-se enquanto ação acadêmica de formação continuada em dois eixos: o primeiro é o de que a Educação a Distância pode ser vista como uma estratégia política de expansão das ações da Universidade. $\mathrm{O}$ segundo, consequência do primeiro, é que a $\mathrm{EaD}$, no tocante à formação de professores, pode ser um espaço privilegiado de acessibilidade desses profissionais que atuam nas redes municipal e estadual de ensino.

Assim, os professores que estudam e pesquisam na área da educação, na UEPB, têm focado as ações acadêmicas de formação, tanto inicial quanto continuada na direção da educação on-line, com foco na prática e na produção do conhecimento, construídos a par- 
tir das vivências de professores da UEPB e de professores do Ensino Médio do Estado da Paraíba.

Os textos aqui expostos, enfileirados sem hierarquização nos remetem a pensar que é possível traçar um novo paradigma para a educação que possibilite aos docentes, em suas práticas em sala de aula, rever suas competências e habilidades para lidar com as Tecnologias da Informação e Comunicação como suportes didático-pedagógicos para ensinar e aprender, de forma virtual, atitudes hoje indispensáveis ao "Ser"professor.

O primeiro texto das autoras Laércia Maria B. de Medeiros e Carolina Cavalcanti Bezerra reflete teoricamente a discussão sobre formação continuada de professores, no Brasil, pautando-se no percurso histórico, social e epistemológico marcado por variadas concepções no âmbito da educação. Nesse sentido, a partir desse referencial teórico, as autoras encontram categorizações temáticas fundamentadas em produções científicas monográficas do curso de Especialização em Tecnologias na Educação, objetivando identificar o que se explicita como temáticas de relevância, além de verificar as demandas e mobilizações de saberes que se articulam com as tecnologias na educação. Fazem ainda algumas reflexões a respeito da necessidade formativa do professor como ponto de partida e de chegada, resultando no entendimento que a unidade teoria e prática são práxis.

O segundo texto de Taíses Araújo da Silva Alves e Robson Pequeno de Sousa trata da disseminação do acesso às Tecnologias Digitais de Informação e Comunicação (TDIC) e a ampliação da oferta de programas de $\mathrm{EaD}$ que trouxe novos desafios para essa modalidade de ensino. Configuram-se novos contextos de ensino e aprendizagem, que provocam transformações no fazer docente e impulsionam mudanças na formação de professores produzidas mediante o adven- 
to da Educação Online. Trata-se de uma Pesquisa Qualitativa de caráter exploratório, constituindo-se de uma elaboração teórica que busca analisar a importância de uma formação continuada de docentes do Ensino Superior para atuar na EaD Online. As experiências formativas na modalidade, apesar de utilizarem diferentes ambientes de aprendizagem com interfaces que possibilitam uma comunicação mais interativa e cooperativa, continuam pautados em práticas pedagógicas baseadas numa educação instrucionista.

No texto seguinte, as autoras Francineide Alves Sales e Maria Lúcia Serafim têm como princípio o grande avanço das tecnologias da informação e comunicação na atualidade, em que se percebeu uma crescente busca pelo conhecimento aliada às formações de redes sociais. Este estudo investigou se os alunos estão utilizando as redes sociais para fins educativos, se professores que participam dessas redes colaboram para construção do conhecimento desses indivíduos e se este fato contribui para uma boa relação entre professores e alunos. O lócus da pesquisa foram duas escolas: uma da rede pública e outra da rede particular de ensino médio, sendo partícipes da pesquisa alunos do $1^{\mathrm{O}}$ ano do ensino médio. Os adolescentes apontaram que o Orkut e o MSN são as redes sociais mais acessadas e que o número de professores conectados aos alunos através de redes sociais ainda é pequeno quando se compara a evolução das tecnologias.

No quarto artigo Carolina Cavalcanti Bezerra e Lúcia Serafim apresentam os preceitos, fundamentos e características da infografia como ferramenta comunicativa propondo seu uso como metodologia de ensino na Educação a Distância. Os resultados alcançados e proposituras iniciais dessa leitura sugerem a utilização da infografia no desenvolvimento de atividades nos Ambientes Virtuais de Apren- 
dizagem e no processo de interação e mediação entre alunos, professores e tutores.

No artigo seguinte, os autores Robson Pequeno de Sousa e Karlete Vânia Mendes Vieira exploram a multimídia como uma ferramenta muito importante na comunicação e sua eficácia no aspecto educacional. O objetivo deste trabalho foi desenvolver e aplicar um Objeto de Aprendizagem baseado nos princípios da multimídia e aplicá-lo no ensino superior da Microbiologia. O estudo foi realizado com uma turma de alunos que cursou o segundo ano de Odontologia da Universidade Estadual da Paraíba. O Objeto de Aprendizagem demonstrou proporcionar uma boa assimilação do conteúdo através dos índices de acertos nos exercícios aplicados após cada módulo, segundo a escala de Likert. O sistema multimídia avaliado pode ser utilizado como recurso didático no ensino superior da Microbiologia, de maneira satisfatória.

No sexto trabalho desta coletânea, as autoras Luzivone Lopes Gomes e Filomena Maria G. S. Cordeiro Moita buscam analisar o uso das Tecnologias da Informação e Comunicação na prática docente em uma escola de Educação Básica. Foram realizadas entrevistas semiestruturadas com 26 professores, com coleta documental e observação in loco. Pesquisa com abordagem qualitativa, de cunho descritivo interpretativo, embasada na contribuição dos autores: Levy (1998); Tardif (2011); Moran (2010); Coscarelli (2006); Mattos (2010); Moita (2011); Valente (2010) e Dubet (2011). Assim buscou-se compreender como utilizar as tecnologias na prática docente, que impulsionam a educação para novos caminhos, buscando a melhoria do ensino e uma educação para formação de uma cidadania ativa.

Rodrigo Lins Rodrigues e Filomena Maria G. S. Cordeiro Moita destacam a introdução da Realidade Aumentada na educação 
como um novo paradigma que relata uma educação de forma dinâmica. Por isso, é importante estarmos atentos para essa nova tendência, bem como para esse novo receptor e suas necessidades. Nesse contexto, o objetivo foi propor uma estrutura para desenvolver um protótipo interativo para a visualização de figuras geométricas, com base em técnicas de realidade aumentada com rastreamento de mãos, que apoiará o professor e os alunos a visualizarem bem mais os conteúdos no campo da geometria espacial. Para tanto, foram utilizadas técnicas de análise de competidores, prototipagem e testes com o usuário. O resultado foi um protótipo funcional, que poderá ser utilizado no campo da Geometria e ser adaptado para outras áreas do conhecimento.

O texto a seguir de autoria de Maria Gracielly Lacerda de Abrantes e Robson Pequeno de Sousa intitulado "Formação Continuada e Conectivismo um estudo de caso referente às transformações da prática pedagógica no discurso do professor"recebeu como escolha metodológica os pressupostos da pesquisa qualitativa exploratória fazendo uso da aplicação de formulário do google drive, objetivando investigar como os professores participantes da formação continuada pelo PROINFO no curso Redes de Aprendizagem, promovido pelo Núcleo de Tecnologia Educacional, localizado na cidade de Patos, no segundo semestre de 2014 se apropriaram daquele conhecimento por meio das TIC.

É a partir desde cenário investigativo que o trabalho dos autores se fundamentou no estudo de George Simens (2004) sobre uma nova abordagem educacional que enfatiza a aprendizagem por meio de redes de conexão.

Pretende-se portanto com esta "amostra" de leitura disponibilizar aos que trabalham com formação de professores mais uma 
oportunidade de discussão sobre o uso das tecnologias da informação e comunicação no âmbito da educação.

Boa leitura,

\section{Prof a Dra Eliane de Moura Silva}

Pró-Reitora de Ensino Médio, Técnico e Educação a Distância 